\title{
Production and Quality Evaluation of Margarine from Blends of Melon and Palm Kernel Oils
}

\author{
Aondoakaa Philip Ityotagher ${ }^{*}$, Chihichan Terhile \\ Department of Food Science and Technology, University of Agriculture, Makurdi, Nigeria \\ Email address: \\ philippi26821@gmail.com (A. P. Ityotagher) \\ ${ }^{*}$ Corresponding author \\ To cite this article: \\ Aondoakaa Philip Ityotagher, Chihichan Terhile. Production and Quality Evaluation of Margarine from Blends of Melon and Palm Kernel \\ Oils. World Journal of Food Science and Technology. Vol. 4, No. 3, 2020, pp. 72-79. doi: 10.11648/j.wjfst.20200403.12
}

Received: July 9, 2020; Accepted: July 28, 2020; Published: August 10, 2020

\begin{abstract}
The potential of margarine production from blends of melon and palm kernel oil was studied. Margarine samples were produced from composite oils containing 100:0, 80:20 and 70:30 melon seed oil and palm kernel oil, respectively. The physico-chemical composition, proximate properties and sensory evaluation were determined using standard methods. All data were subjected to statistical analysis at $5 \%$ level of significance. Proximate values increase for moisture $(6.02-10.33 \%)$, ash (1.34-6.12\%), crude fiber (4.27-6.99\%) and carbohydrate (9.50-10.38\%). Conversely, a decrease in protein and fat values was observed. Results for physico-chemical analyses showed a significant decrease in Iodine value (25.05-18.85) and peroxide value (0.44-0.32) with a remarkable increase in spread ratio (3.15-10.11\%) and total soluble solids (45.32-75.46) but insignificant increase in acid value (1.84-2.30). Result for sensory evaluation showed that sample B had the highest score for all the sensory properties evaluated. However, it was not statistically different $(\mathrm{P}>0.05)$ from sample $\mathrm{C}$ in terms of appearance, taste, aroma and mouth feel. Sample A with $100 \%$ melon oil and the blends (sample B and C) varied significantly $(\mathrm{P}<0.05)$ in all the sensory properties investigated. It was concluded that the blend containing $70 \%$ melon oil and $30 \%$ palm kernel oil had the best potential for the production of margarine which would be acceptable.
\end{abstract}

Keywords: Margarine, Physico-Chemical, Proximate, Sensory, Melon, Palm-Kernel-Oil

\section{Introduction}

Consumer interest in healthy eating is shifting towards the potential health benefits of foods known as functional foods. Functional foods refer to foods which positively affects one or more target functions such as reduction of diseases in the body along with its nutritional effects [1]. The recent trend of moving away from chemical based remedies, towards more nature-based treatments is gaining momentum as a result of the increasing cost of healthcare [2, 3] and comparatively less residue effect associated with functional foods [4].

Margarines were originally produce from lard and other animal fat sources $[5,6]$. However, the linkage of saturated fats with heart disease [7] results to the production of new margarine of vegetable origin. Margarine (a butter substitute) made primarily from vegetable oils is a research innovation. It is recognized as a healthy table spread and a cheaper alternative to butter for use in cooking and in food preparation [6]. Margarine falls under the food group often described as lipid (fats and oils) [8]. Its delivers essential fats and vitamins our body needs. Just like any other fat, it delivers energy and gives food its taste and texture.

The seeds of Egusi melon (Citrullus colocynthis L.) are well known for their rich oil and protein content. Oil constitutes the largest nutritional component of the seed. The seed is reported to contain $32.55 \%$ protein, and $50 \%$ oil [9]. According to Abbah OC., et al. [10] the seed of Egusi melon contains $35 \%$ fats, $10 \%$ carbohydrate and $28 \%$ protein, with $72 \%$ by weight unsaturated fatty acids, and $57.4 \%$ of it being polyunsaturated fatty acids (PUFA). It is well documented that egusi melon oil contains good amounts of linoleic and oleic acid and other essential fatty acids which have protective effect against coronary heart disease [10]. National Research Council [11] reported that its fatty-acid makeup as $63 \%$ linoleic and $16 \%$ oleic. 
In addition to its possible effect on lowering of blood cholesterol due to the presence of unsaturated fatty acid, the Egusi melon seed can also be an exceptional tool for combating protein-calorie malnutrition owing to its protein high nutritional quality. Egusi melon seed has an amino acid profile that compares favorably with that of soybeans and even white of an egg [11,12]. According to National Research Council [11] Studies conducted to determine the impact of egusi as a source of protein and fat in the diet of young children who show the signs of deficient calories (marasmus) and deficient protein (kwashiorkor) has proved to be satisfactory. Additional dietary bonuses come from its levels of vitamins (thiamin and niacin) and minerals [13].

Palm kernel oil (PKO) is high in lauric acid and has a sharp melting, a character suitable for use in confectionary fats [14].

Although egusi is an important food commodity even by global specification, it is not well known to nutritionists outside a few West African nations. Egusi melon seed is one of the underutilized crops in Africa. It is grown in large quantity but is currently mainly used as a soup thickener. However, it offers diverse opportunities for the world's food technologists to help reduce African hunger. For example, it can become a healthy oil and protein means in many processed foods as well as a supplement to cereal and root-based staples. Production of margarine from blends of Egusi melon seed oil and palm kernel oil will improve the utilization and value of the melon seed. Also, consumption of margarine made from these oils rich in poly unsaturated fatty acids (PUFAs) and mono unsaturated fatty acids (MUFAs) may help in the management of the quality of fat in consumer's diet, given that they are consumed as part of a balanced and varied diet [15]. Thus this present study aimed to investigate the potential of producing margarine from blends of Egusi melon and palm kernel oil and to determine its physicochemical, sensory qualities and overall acceptability of the product.

\section{Materials and Methods}

\subsection{Raw Material Procurement}

Egusi melon and palm kernel seeds were purchased from wurukum market, Makurdi, Benue State. Packaging materials (plastic containers), plastic spoons, vanilla flavor, emulsifier (distilled monoacylgycerols, 90\% monoester), antioxidant (vitamin E), colour (betacarotene), skim milk powder and dried salt were purchased from modern market, Makurdi, Benue State.

\subsection{Preparation of Raw Materials}

\subsubsection{Preparation of Palm Kernel Oil}

The palm kernel oil was prepared by the mechanical extraction method as described by Wanessa AC., et al. [16] (figure 1).

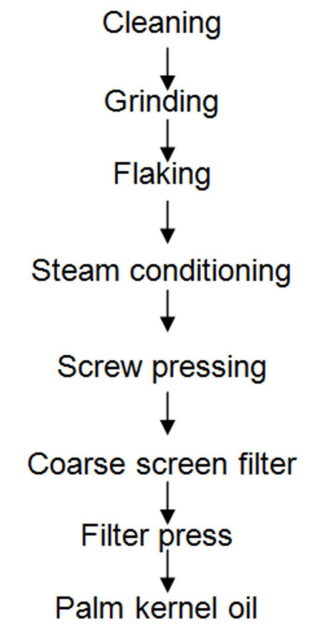

Source: Wanessa AC., et al. [16]

Figure 1. Flow Chart for the Extraction of Palm Kernel Oil.

\subsubsection{Preparation of Egusi Melon Oil}

Egusi melon oil was prepared using the method described by Ejoh SI and Ketiku OA [17] with modifications (figure2). The procured egusi melon seeds were sorted and washed to remove dirt and other extraneous materials such as sands, sticks, leaves and debris. The sorted and washed melon seeds were oven dried and then roasted in a dry pot until they became very brown. After cooling, it was then milled into paste without the addition of water using a wet miller. The paste was pressed with clean hands continuously. Little water was added at intervals during pressing. The extracted oil was then collected. The oil was filtered using a double layer of cheese cloth to remove solid particles present in it. The moisture was removed by oven drying at $105^{\circ} \mathrm{C}$ for one hour and it was stored at $8^{\circ} \mathrm{C}$ until it was used.

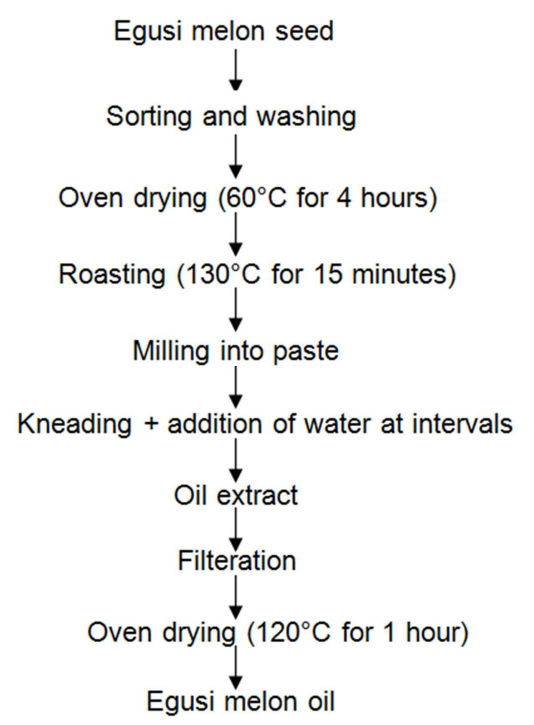

Source: adapted from Ejoh SI and Ketiku OA [17]

Figure 2. Flow Chart for the Extraction of Egusi Melon Oil.

\subsubsection{Blend Formulation}

Two different blends were formulated based on egusi 
melon oil and palm kernel oil in the ratios of 80:20 and 70:30 respectively as shown in Table 1.

Table 1. Blends Formulation.

\begin{tabular}{lll}
\hline Samples & Melon oil $(\mathbf{m l})$ & Palm kernel oil $(\mathbf{m l})$ \\
\hline A (Control) & 100 & 0 \\
B & 80 & 20 \\
C & 70 & 30 \\
\hline
\end{tabular}

KEY:

Sample A: $100 \%$ melon oil.

Sample B: $80 \%$ melon oil and 20\% palm kernel oil.

Sample C: $70 \%$ melon oil and 30\% palm kernel oil.

\subsection{Production of Margarine from Blends of Egusi Melon and Palm Kernel Oil}

Margarine was produced from 100\% melon oil (control) and each of the two blends (80:20 and 70:30) according to the method described by Sayed AH., et al.[18]. A basic recipe that included $81.7 \%$ oil blend, $0.3 \%$ emulsifier, $16 \%$ water, $0.8 \%$ salt, $0.9 \%$ skim milk powder, $0.2 \%$ flavour, $0.01 \%$ antioxidant and $0.003 \%$ colour was used for margarine production. Emulsifier, antioxidant, flavor and color were disolved in the heated oil phase. Salt and skim milk powder were dissolved in the water phase. The water phase was added gradually to the oil phase while agitating it to form a nice emulsion. For the solidification of margarine, the emulsion was stirred for 10 minutes and then cooled in ice bath containing $10 \%$ sodium chloride $(\mathrm{NaCl})$. The emulsion was then mixed and solidified at a temperature of $11^{\circ} \mathrm{C}$. The margarine samples were labeled"A $(100: 0)$ ", "B (80:20)" and "C (70:30)" corresponding to the control and the blends, respectively and stored in a refrigerator at $4{ }^{\circ} \mathrm{C}$.

\subsection{Proximate Analysis}

Proximate analysis (fat, ash, moisture, protein and crude fibre) of the margarine samples was determined according to the method described by AOAC [19]: The ash by muffle furnace ignition method; moisture by oven drying method; protein by macro kjeldah method; fat by soxhlet solvent extraction method. Carbohydrate content was determined by calculation using the difference method as described by Olagunju A., et al.[20].

\subsection{Physico-chemical Analysis}

Acid value, Iodine value and peroxide value were determined by the methods described by Onwuka GI [21]. Total soluble solids were determined as described by Ndife $\mathbf{J}$ [22] while spread ration was determined by the method described by Agu HO., et al.[23].

\subsection{Sensory Evaluation}

The margarine samples were coded and presented to a 20member panel consisting of students and lecturers for evaluation based on the following characteristics; appearance, aroma, taste, mouth feel and general acceptability using a 9point hedonic scale, where 9 indicates extremely like and 1 extremely dislike as described by Ihekoronye IA and Ngoddy PO [24].

\subsection{Statistical Analysis}

Analysis of variance (ANOVA) was carried out on the data obtained to detect statistical differences at 5\% level of significance, while the least significant test was used to separate the means. All statistical analyses of data were performed using SPSS (version 20.0) software.

\section{Results and Discussion}

\subsection{Proximate Composition of Margarine Produced from Blends of Egusi Melon Seed Oil and Palm Kernel Oil}

The proximate composition result of margarine produced from blends of egusi melon oil and palm kernel oil is presented in Table 2. There were significant differences $(p<0.05)$ between the control (sample A) and the blend samples (sample B and C) for moisture, ash and and crude fibre. No significant differences $(p>0.05)$ were observed between all samples for crude fat and carbohydrate. The moisture content of the margarine samples ranged from $6.02 \%$ in sample A to $10.33 \%$ in sample C. Codex Alimentarius commission [25] approve maximum water content of margarine as $16 \%$. The moisture content of all the samples conforms to Codex standard. The moisture content of food indicates its microbial stability and keeping qualities [26, 27]. Therefore, the low moisture content of the samples is an indication of safety and microbial stability. The protein content decreased with the increase in the level of palm kernel oil in the blends. The protein content of the $100 \%$ melon oil margarine was $12.52 \%$ as compared to 9.34 and $8.26 \%$ for the blends containing 20 and $30 \%$ palm kernel oil, respectively. The trend was the same for fat. This is a reflection of the superior protein and fat properties of melon oil over palm kernel oil. Conversely, the carbohydrate, crude fiber and ash contents of the blends increased with the increase in the level of palm kernel oil in the blends. The moisture and fat values compared favourably with the standard of $\leq 16$ and $\geq 80$ respectively reported by Codex Alimentarius commission [25].

Table 2. Proximate Composition of Margarine Produced from Blends of Egusi Melon Seed and Palm Kernel Oils.

\begin{tabular}{|c|c|c|c|c|}
\hline \multirow{2}{*}{ Parameters } & \multicolumn{3}{|c|}{ Samples } & \multirow{2}{*}{ LSD } \\
\hline & A(100:0) & B (80:20) & C (70:30) & \\
\hline Moisture & $6.02^{\mathrm{b}} \pm 0.12$ & $9.83^{\mathrm{a}} \pm 0.16$ & $10.33^{\mathrm{a}} \pm 0.11$ & 1.29 \\
\hline Protein & $12.52^{\mathrm{a}} \pm 0.13$ & $9.34^{\mathrm{ab}} \pm 0.14$ & $8.26^{\mathrm{b}} \pm 0.18$ & 3.48 \\
\hline Ash & $1.34^{\mathrm{b}} \pm 0.16$ & $5.66^{\mathrm{a}} \pm 0.18$ & $6.12^{\mathrm{a}} \pm 0.17$ & 0.99 \\
\hline Crude fat & $64.34^{\mathrm{a}} \pm 0.17$ & $58.42^{\mathrm{a}} \pm 0.16$ & $50.23^{\mathrm{a}} \pm 0.12$ & 16.08 \\
\hline Crude fiber & $4.27^{\mathrm{b}} \pm 0.14$ & $6.34^{\mathrm{a}} \pm 0.16$ & $6.99^{\mathrm{a}} \pm 0.18$ & 1.92 \\
\hline
\end{tabular}




\begin{tabular}{lllll}
\hline \multirow{2}{*}{ Parameters } & \multicolumn{5}{c}{ Samples } & LSD \\
\cline { 2 - 5 } & $\mathbf{A}(\mathbf{1 0 0 : 0 )}$ & $\mathbf{B}(\mathbf{8 0 : 2 0})$ & $\mathbf{C}(\mathbf{7 0 : 3 0 )}$ & 6.33 \\
\hline Carbohydrate & $9.50^{\mathrm{a}} \pm 0.09$ & $10.10^{\mathrm{a}} \pm 0.13$ & $10.38^{\mathrm{a}} \pm 0.12$ & \\
\hline
\end{tabular}

Values are means \pm SD duplicate determinations. Means with different superscript within the same row are significantly different $(\mathrm{P}<0.05)$. Means with the same superscripts within the same row are not significantly different $(\mathrm{P}>0.05)$.

KEY:

LSD: Least Significant Difference.

Sample A: $100 \%$ melon oil.

Sample B: $80 \%$ melon oil and $20 \%$ palm kernel oil.

Sample C: $70 \%$ melon oil and 30\% palm kernel oil.

\subsection{Physico-chemical Properties of Margarine Produced from Egusi Melon Seed Oil and Palm Kernel Oil}

Results of the physico-chemical properties of margarine produced from blends of melon and palm kernel oil is presented in Table 3. There were significant differences $(p<0.05)$ between the control (sample A) and the blend samples (sample B and C) for spread ratio, iodine value and peroxide value. However, no significant differences $(\mathrm{p}>0.05)$ were observed between all samples for acid value and total soluble solid (TSS).

The acid value of the margarine samples ranged from 1.84 in sample A to 2.30 in sample $\mathrm{C}$. The maximum acceptable level of acid in the oil that can find application in cooking is $4 \mathrm{mgKOH} / \mathrm{g}$ [25]. Acid value measures the free fatty acids (FFA) present in lipid. Increment in FFA in a sample of oil or fat indicates hydrolysis of triglycerides. Since such reaction results from the action of lipase enzyme [21], high acid value can be use as an indicator of inadequate processing and storage conditions. The low and slight increase of the acid value of the margarine samples may be attributed to the effective destruction or inhibition of enzymes activity and indicates adequate processing [28].

The peroxide value of the samples ranged from 0.32 in sample $\mathrm{C}$ to 0.44 in sample $\mathrm{A}$. The values of peroxide recorded in this study were similar with the results obtained by Azizkhani M and Zandi P [29]. The peroxide value is an index of quality and stability of oils [8]. It serves as a useful indicator of the extent of oxidation of lipids, fats, and oils and has been associated with the rancidity in lipid-containing food products [30]. According to Onwuka GI [21], a rancid taste begins to show up when the peroxide value is between 20 and $40 \mathrm{meq} / \mathrm{kg}$.

Spread ratio indicates the rate of dissociation of hydrogen bond in the margarine when heated. The spread ratio of the sample produced were $3.15 \%, 9.09 \%$ and $10.11 \%$ for sample $\mathrm{A}, \mathrm{B}$ and $\mathrm{C}$ respectively. The iodine value, a direct measure of double bond (unsaturation), of the margarine samples was high and ranges from 18.85 in sample $\mathrm{C}$ to 25.05 in sample A Intake of essential fatty acids derived from poly unsaturated fatty acids is critical for human health as it is reported to lower serum cholesterol level [31].

Table 3. Physico-chemical Properties of Margarine Produced from Blends of Egusi Melon Seed and Palm Kernel Oils.

\begin{tabular}{|c|c|c|c|c|}
\hline \multirow{2}{*}{ Parameters } & \multicolumn{3}{|c|}{ Samples } & \multirow{2}{*}{ LSD } \\
\hline & $A(100: 0)$ & B (80:20) & $\mathrm{C}(70: 30)$ & \\
\hline Spread ratio $(\%)$ & $3.15^{\mathrm{b}} \pm 0.11$ & $9.09^{\mathrm{a}} \pm 0.13$ & $10.11^{\mathrm{a}} \pm 0.10$ & 1.35 \\
\hline Acid value $(\mathrm{mgKOH} / \mathrm{g})$ & $1.84^{\mathrm{a}} \pm 0.09$ & $1.92^{\mathrm{a}} \pm 0.91$ & $2.30^{\mathrm{a}} \pm 0.13$ & 1.32 \\
\hline Iodine value $\left(\mathrm{gI}_{2} / 100 \mathrm{~g}\right)$ & $25.05^{\mathrm{a}} \pm 0.01$ & $23.30^{\mathrm{b}} \pm 0.01$ & $18.85^{\mathrm{c}} \pm 0.18$ & 6.02 \\
\hline Peroxide value (meq/kg) & $0.44^{\mathrm{a}} \pm 0.01$ & $0.40^{\mathrm{b}} \pm 0.01$ & $0.32^{\mathrm{c}} \pm 0.02$ & 2.00 \\
\hline
\end{tabular}

Values are means $\pm \mathrm{SD}$ duplicate determinations. Means with different superscript within the same row are significantly different $(\mathrm{P}<0.05)$. Means with the same superscripts within the same row are not significantly different $(\mathrm{P}>0.05)$.

KEY:

LSD: Least Significant Difference.

Sample A: $100 \%$ melon oil.

Sample B: $80 \%$ melon oil and 20\% palm kernel oil.

Sample C: $70 \%$ melon oil and 30\% palm kernel oil.

\subsection{Sensory Properties of Margarine Produced from Blends of Egusi Melon Seed Oil and Palm Kernel Oil}

The mean sensory scores of the organoleptic evaluation and acceptability for the margarine samples are presented in Table 4. From the result, sample B which contain $80 \%$ melon oil and $20 \%$ palm kernel oil had the highest score of 7.90 , $7.91,7.82,8.10$ and 8.10 for appearance, taste, aroma, mouth feel and general acceptability respectively but was not significantly different $(\mathrm{P}>0.05)$ from sample $\mathrm{C}$ in terms of appearance, taste, aroma and mouth feel. However, sample A with $100 \%$ melon oil and the blends (sample B and C) varied significantly $(\mathrm{P}<0.05)$ in all the sensory properties investigated.

Table 4. Mean Sensory Score of Margarine Produced from Blends of Egusi Melon Seed and Palm Kernel Oils.

\begin{tabular}{|c|c|c|c|c|}
\hline \multirow{2}{*}{ Parameters } & \multicolumn{3}{|c|}{ Samples } & \multirow{2}{*}{ LSD } \\
\hline & A (100:0) & B (80:20) & C (70:30) & \\
\hline Appearance & $4.30^{\mathrm{b}}$ & $7.90^{\mathrm{a}}$ & $6.24^{\mathrm{a}}$ & 2.09 \\
\hline Taste & $5.10^{\mathrm{b}}$ & $7.91^{\mathrm{a}}$ & $6.50^{\mathrm{a}}$ & 1.34 \\
\hline
\end{tabular}




\begin{tabular}{lllll}
\hline Parameters & \multicolumn{3}{c}{ Samples } & LSD \\
\cline { 2 - 5 } & $\mathbf{A ( 1 0 0 : 0 )}$ & $\mathbf{B}(\mathbf{8 0 : 2 0 )}$ & $6.72^{\mathrm{a}}$ & 1.63 \\
Aroma & $5.10^{\mathrm{b}}$ & $7.82^{\mathrm{a}}$ & $6.80^{\mathrm{a}}$ & 3.24 \\
Mouthfeel & $3.61^{\mathrm{b}}$ & $8.10^{\mathrm{a}}$ & $6.76^{\mathrm{b}}$ & 1.36 \\
General Acceptability & $5.10^{\mathrm{c}}$ & $8.10^{\mathrm{a}}$ & & \\
\hline
\end{tabular}

Means with different superscript within the same row are significantly different $(\mathrm{P}<0.05)$. Means with the same superscripts within the same row are not significantly different $(\mathrm{P}>0.05)$.

KEY:

LSD: Least Significant Difference.

Sample A: $100 \%$ melon oil.

Sample B: $80 \%$ melon oil and $20 \%$ palm kernel oil.

Sample C: $70 \%$ melon oil and 30\% palm kernel oil.

\section{Conclusion and Recommendations}

The nutritional, chemical and sensory value of the margarine samples produced was dependent on the proportion of melon oil and palm kernel oil. Proximate and physico-chemical evaluation of the margarine samples produced from the blends showed an increased nutritive value and stability which compare favouranly to the control (all melon oil margarine). Sample C which contains 70\% melon oil and 30\% palm kernel oil was found to be nutritionally and chemically superior in most attributes than the other samples, making it a good source of nutrients. Although sample B received the highest ratings in all the sensory properties evaluated, it was not significantly different $(\mathrm{P}>0.05)$ from sample $\mathrm{C}$ in those properties. Therefore the blend containing 30\% palm kernel oil had the best potential for the production of margarine which would be acceptable and is recommended.

\section{References}

[1] Ozcan O, Ozcan T, Yilmaz-Ersan L, Akpinar-Bayizit A, Delikanli B (2016) The Use of Prebiotics of Plant Origin in Functional Milk Products. Food Science and Technology 4 (2): $15-22$.

[2] Siró I, Kàpolna E, Kàpolna B, Lugasi A (2008) Functional Food, Product Development, Marketing and Consumer Acceptance-A review. Appetite 51 (3): 456-467.

[3] Martirosyan DM, Singh J (2015) A New Definition of Functional Food by FFC: WhatMakes a New Definition Unique?. Functional Foods in Health and Disease 5 (6): 209223.

[4] Ansari S, Chauhan B, Kalam N, Kumar G (2013) Current Concepts and Prospects of Herbal Nutraceutical: A review. Journal of Advanced Pharmaceutical Technology and Research 4 (1): 4.

[5] Vaisey-Genser M (2003) Margarine: Types and Properties. Encyclopedia of Food Sciences and Nutrition ( $2^{\text {nd }}$ ed).

[6] acqueline B, Marcus MS (2013) Lipids Basics: Fats and Oils in Foods and Health. Culinary Nutrition.

[7] Narges E, Manochehr B, Parvin E (2016) Comparison of Physicochemical Characteristics of Some Margarines andButters in Iranian Market during Storage. Journal of Pharmaceutical and Health Sciences 4 (3), 181-192.
[8] Mahboubeh Z, Yahya M, Peyman A (2014) The Changes of Table Margarine Characterization During Storage Time. European Journal of Experimental Biology 4 (3): 185-187.

[9] Peter AO (2018) Determining the Physiochemical and Phytochemical Properties of Local Nigerian White Melon Seed Flour. International Journal of ResearchGRANTHAALAYAH 6 (5): 2394-3629.

[10] Abbah OC, Musa AD, Ejembi D, Omale J, Sanni M, et al (2015) Medicinal Utility of Egusi Melon (Citrullus colocynthis L.). International Journal of Current Research in Biosciences and Plant Biology 2 (7): 185-191.

[11] National Research Council (2006) "8 Egusi”. Lost Crops of Africa: Volume II: Vegetables. Washington, DC: The National Academies Press.

[12] Zead HM, Haiane RL, Petro S, Ivan C, Ihab IA, et al (2016) Comparative Study of Amino Acid Composition in the Seeds, Pulp and Rind from Citurllus colocynthis Fruits. International Journal of Pharmacognosy and Phytochemical Research 8 (3): 433-437.

[13] Akobundu ENT, Cherry JP, Simmons JG (1982) Chemical, Functional and Nutritional Properties of Egusi (Colocynthis citrullus) Seed Protein Products. Journal of Food Science 47: 3.

[14] Noor LH, Rafidah AH, Sivaruby K, Wan RA, Norazura AM, et al (2017) Palm Kernel Oil: Versatile Ingredients for Food Applications. Journal of Oil Palm Research 29: 487-511.

[15] Ashok RP, Jean-Michel L, Sarah S, Koen D (2016) The Contribution of Modern Margarine and Fat Spreads to Dietary Fat Intake. Comprehensive Reviews in Food Science and Food Safety 15 (3): 433-541.

[16] Wanessa AC, Cinthya EP, Fernanda WF, Mozaniel SO, Priscila NB (2019) Obtainment, Applications and Future Perspectives of Palm Kernel. African Journal of Biotechnology 18 (5): 101-111.

[17] Ejoh SI, Ketiku OA (2013) Vitamin E Content of Traditionally Processed Products of Two Commonly Consumed Oilseeds Groundnut (Arachis Hypogea) and Melon Seed (Citullus Vulgaris) in Nigeria. Journal of Nutrition and Food Science3 (2): 187

[18] Sayed AH, Miskandar MS, Mahdi K, Javad K (2009) The Production of an Experimental Table Margarine Enriched with Conjugated Linoleic Acid (CLA): Physical Properties. Journal of the American Oil Chemists' Society 86: 453-458.

[19] AOAC (2005). Official Methods of Analysis of Association of Official and Analytical Chemists. Washington DC $\left(18^{\text {th }} \mathrm{ed}\right)$. 
[20] Olagunju A, Muhammed A, Aliyu S, Mada SB, Isah R, et al (2013). Nutritional Values of Powdered Milk Commercially Consumed in West Africa. International Journal of Food Nutrition and Safety 4 (2): 55-61.

[21] Onwuka GI (2005) Food Analysis and Instrumentation: Theory and Practice. Lagos, Nigeria: Naphtali Prints.

[22] Ndife J (2014). Production and Quality Assessment of Functional Yoghurt Enriched with Coconut. International Journal of Nutrition and Food Science 3 (6): 545-550.

[23] Agu HO, Ayo JA, Paul AM, Folorunsho F (2007) Quality Characteristics of Biscuits Made from Wheat and African Breadfruit (Treculia africana). Nigerian Food Journal 25 (2): 19-27.

[24] Ihekoronye IA, Ngoddy PO (1985) Integrated food science and technology forthe tropics. Macmillian Publishers Ltd, London.

[25] Codex Alimentarius commission (1982) Recommended international Standards for Edible Arachis oil 11 (1sted), FAO/WHO: Rome.

[26] Dubale B (2014) Factors Affecting Quality of Grain Stored in
Ethiopian Traditional Storage Structures and Opportunities for Improvement. International Journal of Sciences: Basic and Applied Research 18 (1): 235-257.

[27] Sengev IA, Nwobi IS (2016) Effect of Crayfish Inclusion on the Chemical and Sensory Properties of Ogi Prepared from Maize, Millet and Sorghum. International Journal of Nutrition and Food Sciences 5 (6): 378-383.

[28] Adel IA, Fatima ES, Mohamed AE (2018) Acid, Peroxide, Ester and Saponification Values for Some Vegetable Oils Before and After Frying. AASCIT Journal of Materials 4 (2): 43-47.

[29] Azizkhani M, Zandi P (2010) Effects of some natural antioxidant mixtures on margarine stability. Pak. J. Agr. Sci. 47 (3): 251-257.

[30] Saadet D, Seda C, Bilgehan D (2012) Determination of Peroxide Values of Some Fixed Oils by Using the mFOX Method, Spectroscopy Letters: An International Journal for Rapid Communication 45 (5): 359-363.

[31] Lokuruka M (2010) Soya Nutritional Properties. African journal of food agriculture nutrition and development 10 (4): 2439-2459. 